\title{
Keterlibatan Organisasi Eksternal Dalam Penyusunan RPJM desa Di Desa Bringinan Jambon Ponorogo
}

\author{
${ }^{1}$ Rizky Yoga Dwi Cahya, ${ }^{2}$ Robby Darwis Nasution \\ ${ }^{12}$ FISIP, Universitas Muhammadiyah, Ponorogo \\ Email: ${ }^{1}$ rizkyyoga017@gmail.com, ${ }^{2}$ darwisnasution69@gmail.com
}

\begin{abstract}
Abstrak. Perubahan sosial mendorong masyarakat untuk lebih maju lagi dalam menyatukan aspirasinya dan membentuk sebuah organisasi yang independent. Di Desa Bringinan terbentuknya salah satu organisasi eksternal yaitu KOPI (Komunitas Pekerja Imigran). Organisai eksternal ini tidak hanya berfokus pada kegiatan sosial saja tetapi organisasi ini membantu pemerintah desa dalam penyusunan RPJMDesa, progam-progam organisasi ini juga menginisiasi pemerintah desa dalam melakukan pendataan tentang masyrakat Desa Bringinan sehingga mendapatkan data akurat yang akan di jadikan acuan pemerintah desa bringinan dalam melakukan penyusunan RPJMDesa. Hal ini menjawab beberapa permasalahan yang terjadi dimasyarakat, yakni kurangnya partisipasi masyarakat dalam penyusunan RPJMDesa. Dengan adanya organisasi eksternal KOPI, aspirasi masyarakat dapat tersalurkan dan penyusunan RPJMDesa akan lebih efektif. Penelitian ini menggunakan jenis penelitian kualitatif desktriptif. Sumber data yang di gunakan ini ada dua jenis yaitu sumber data primer dan data sekunder. Teknik pemilihan informan yang di pilih adalah teknik proposive sampling dengan informan yang di pilih Kepala Desa Bringinan, Pembimbing KOPI (lsm), dan anggota KOPI. Kesimpulan dari penelitian adalah keterlibatan organisasi eksternal dalam melakukan penyusunan RPJMDesa dengan cara melakukan pendataan masyrakat desa secara langsung sehingga mendapatkan hasil yang akurat sehingga mempermudah pemerintah Desa Bringinan dalam menyaring aspirasi masyarakat Desa Bringinan dan memasukannya ke RPJM Desa
\end{abstract}

\section{Kata kunci : Keterlibatan, Organisasi eksternal, RPJMDesa}

\begin{abstract}
Social change pushes people forward to unite their aspirations and form independent organizations. In the village of Bringin, an external organization was formed, the KOPI (Community of Immigrant Workers). This external organization not only supports social activities, but this organization helps the village government in the village medium term development plan, programs, the organization also initiates the village government in conducting data collection on the community. prepare the village medium term development plan. This answers a number of questions that occur in the community, namely participation in the preparation of the village medium term development plan. With the existence of an external organization KOPI, community aspirations can be channeled and make the village medium term development plan more effective. This research uses descriptive qualitative research type. Data sources used are of two types, namely primary data sources and secondary data. The selected informant selection technique is the proportional sampling technique with the informant selected by the Head of the Bringin Village, the KOPI Advisor (NGOs), and the KOPI members. The conclusion of the research is the participation of external organizations in conducting the village medium term development plan by directly collecting data from the village community to produce accurate results making it easier for the village government of Bringin in filtering the aspirations of the people of the village of Bringin and including it in the village medium term development plan.
\end{abstract}

Keywords: Involvement; External organization; Village medium term development plan 


\section{PENDAHULUAN}

Pembangunan desa merupakan salah satu pemanfaatan untuk salah satu kesejahteraan masyarakat yang nyata, baik dari segi perekonomian masyarakat, kesempatan lapangan pekerjaan, kesempatan usaha, aspek dalam pengambilan keputusan maupun indeks pembangunan manusia (SE Mendagri No 414.2/1408 PMD Tahun 2010). Menurut UU No. 6 tahun 2014, untuk mencapai pembangunan desa yang ideal, pembangunan dalam desa melalui tahapan dengan adanya perencanaan dan pengawasan. RPJMDesa merupakan dokumen perencanaan untuk periode 6 (enam) tahun yang memuat isi visi dan misi kepala desa, arah kebijakan desa, kegiatan desa, penyelenggaraan kebijakan, pembangunan desa, dan pemberdayaan masyarakat desa (Permendagri No 114 tahun 2014). Dalam penyusunan RPJMDesa melibatkan partisipatif masyarakat agar terciptanya rencana pembangunan yang sesuai dengan kebutuhan masyarakat. Rahman (2012) mengatakan adanya partisipasi masyarakat semakin membuka peluang rencana pembangunan desa yang sesuai dengan harapan dan kebutuhan masyarakat. Di Kabupaten Ponorogo tepatnya di Desa Bringinan Kecamatan Jambon pembentukan RPJMDesa melibatkan salah satu organisasi eksternal dengan bimbingan Infest dari Yogyakarta dengan kontrak selama 3 tahun. organisasi eksternal ini adalah (PMI) Pekerja Migran Indonesia, menurut Barno selaku Kepala Desa mengatakan dengan adanya organisasi ini penyusunan RPJMDesa dengan melibatkan beberapa anggota seperti Pejabat Desa, BPD, Tokoh Masyarakat akan lebih tercipta rencana pembangunan desa yang sesuai harapan masyarakat.(Rahman et al., 2014)

Penelitian SEPTIANA

mengatakan bahwa 2015-2020 terdapat keterlibatan masyarakat, di tahap keadaan desa dan pembahasan RPJMDesa partisipasi masyarakat pada suatu wilayah atau suatu kegiatan tentu memiliki karakterisitik yang beragam dari segi bentuk maupun karakteristiknya. Berkaitan hal tersebut SLAMET (1992) mengatakan bahwa bentuk partisipasi masyarakat dalam keikutsertaan pembangunan desa dan penyusunan RPJMDesa dapat dikategorikan menjadi 3 yaitu bentuk partisipasi dalam perencanaan, bentuk partisipasi dalam pelaksanaan, dan bentuk partisipasi dalam pemanfaatan. Bentuk partisipasi dalam perencanaan dapat dikategorikan kehadiran masyarakat dalam rapat penyusunan RPJM Desa, kritik masyarakat, atau penyampaian saran. Masyarakat Desa Bringinan terkadang tidak berani untuk menyampaikan aspirasinya maka pemerintah Desa Bringinan mempunyai inovasi dibentuknya suatu wadah aspirasi masyarakat yang di dalamnya beranggotakan masyarakat Desa Bringinan dengan perangkat Desa Bringinan sendiri.(RAHMA FITRIAYU SARI, 2019)

Perubahan sosial mendorong masyarakat untuk lebih maju lagi, dengan menyatukan aspirasi, dan menyuarakan sebuah kampanye dengan membentuk suatu organisasi yang bersifat independent. Organisasi adalah salah satu kelompok orang dalam suatu wadah untuk mencapai tujuan bersama, organisasi masyarakat dan (LSM) Lembaga Swadaya Masyarakat atau istilah lainnya Non-Govermmental Organization (NGO) memegang peranan penting sebagai pilar demokrasi yang mewujudkan masyarakat sipil (civil society) yang mampu memperjuangkan hak-hak rakyat dalam kehidupan bernegara. Di Indonesia organisasi masyarakat dan LSM sudah di atur dalam Pasal 28 Undang- Undang Dasar 1945. Ada beberapa jenis organisasi yang terbentuk di masyarakat yaitu LSM, Yayasan sosial, organisasi keagamaan, organisasi kepemudaan dan organisasi yang di dasarkan oleh profesi. Di dirikan organisasi masyarakat ini didasari oleh kesamaan aspirasi, kepentingan, kegiatan, dan tujuan berpartisipasi dalam pembangunan demi tercapainya tujuan Negara Kesatuan Republik Indonesia (NKRI) yang berlandaskan Pancasila dan Undang- Undang 1945. Organisasi adalah suatu wadah atau tempat berkumpulnya sekelompok orang untuk bekerja sama secara rasional, sistematis, terkendali, dan terpimpin untuk mencapai suatu tujuan tertentu dengan memanfaatkan sumber daya yang ada. 
Purnama Sari (2008), menyatakan bahwa partisipasi masyarakat dalam proses perencanaan pembangunan di Kecamatan Cibadak, Kabupaten Sukabumi masih lemah karena beberapa tahapan proses perencanaan pembangunan masing-masing desa belum di laksanakan dan keterlibatan masyarakat dalam penentuan prioritas progam di tingkat kecamatan belum terwujud. Hal ini berbeda dengan Desa Bringinan Kecamatan Jambon Kabupaten Ponorogo. Penyusunan RPJMDesa dengan melibatkan kepala desa, BPD, peran aktif tokoh masyarakat serta organisasi eksternal desa yakni KOPI. Hal ini menjadi menarik karena dalam penyusunan RPJMDesa, Desa Bringinan merupakan satusatunya desa yang melibatkan organisasi eksternal desa. Selain itu jika kita melihat undang-undang terkait dengan penyusunan RPJMDesa maka keterlibatan masyarakat akan diwakili oleh tokoh masyarakat dan BPD. Maka dari itu apa yang terjadi di desa Bringinan dengan mengikut sertakan nongovermental organization (LSM) KOPI dalam penyusunan RPJMDesa menarik diteliti lebih lanjut. Dimana fokus yang menarik diteliti adalah keterlibatan KOPI dalam penyusunan RPJMDesa serta seberapa besar pengaruh organisasi eksternal dalam penyusunan RPJM Desa?

\section{METODE PENELITIAN}

Jenis penelitian ini adalah penelitian kualitatif. Penelitian ini menekankan pada proses induktif yang mulai dari pengumpulan data lalu ke tema umum menuju ke teori atau kosep tertentu. Informan dari penelitian ini adalah Kepala Desa Bringinan, Pembimbing dari KOPI, dan anggota KOPI. Sesuai dengan jenis penelitian, bahwa penelitian kualitatif tidak menggunakan pendekatan populasi dan sampel tetapi yang digunakan adalah pendekatan secara berlangsung intensif ke informan yang akan dijadikan sebagai sumber data dalam melakukan penelitian ini. Alasan mengambil Desa Bringinan karena terdapat salah satu orgnaisasi eksternal yang beranggotakan pekerja imigrsn yang ikut dalam melakukann penyusunan RPJM Desa. Pengumpulan data dalam penelitian ini melalui observasi, wawancara mendalam dan studi literatur. Observasi merupakan pengamatan yang di dalamnya peneliti langsung turun ke lapangan untuk mengamati perilaku dan aktifitas individu-individu di lokasi penelitian. Wawancara adalah bentuk kegiatan dengan cara menanyakan langsung pada sumber informasi. Sumber sekunder dalam penelitian ini adalah berupa buku, teks dan karya ilmiah sejenis lainnya. Teknik analisis data menggunakan analisis deskriptif kualitatif, yaitu memberikan suatu gambaran tentang kenyataaan yang ada untuk selanjutnya dianalisa guna dapat menemukan hasil yang akhirnya dapat ditarik kesimpulan dan dijadikan landasan dalam memberikan saran-saran dan pendapat dari penulis. (Raco, n.d.)

\section{Hasil dan pembahasan}

\section{a. Teori Organisasi}

Teori organisasi yang berkembang mulai awal abad ke 29 di gunakan ke dalam teori organisasi klasik atau disebut juga teori tradisioanal atau mesin. Pada masa ini organisasi divisualkan sebgai kelompok orang yang membenruk lembaga-lembaga tiap bagian organisasi tersebut memiliki spesialisasi dab sentralisasi dalam tugas dan wewenang. Definisi organisasi menurut teori klasik, organisasi merupakan suatu hubungan, kekuasaan, tujuan, peranan, kegiatankegiatan, komunikasi dan faktor-faktor lain apabila orang bekerjasama.

Teori ini biasa disebut dengan "Teori Tradisional" atau disebut juga "Teori Mesin". Dalam teori ini organisasi digambarkan sebuah lembaga yang tersentralisasi dan tugas-tugasnya terspesialisasi serta memberikan petunjuk mekanistik structural yang kaku tidak mengandung kreativitas.

$$
\text { Teori organisasi birokrasi }
$$

berkembang dalam ranah ilmu sosiologi dan menekankan pada aspek legal rasional. Legal dalam hal ini dimaknai sebagai bentuk wewenang yang dirumuskan dengan jelas berkaitan dengan aturan prosedur dan peranan masing-masing elemen. Sementara rasional mengacu pada suatu tujuan yang jelas dan ditetapkan bersama. Lubis dan Husaini (1987) mengatakan bahwa yang dimaksud dengan 
organisasi adalah suatu kesatuan sosial dari sekelompok manusia, yang berinteraksi menurut suatu pola tertentu sehingga setiap anggota organisasi memiliki fungsi dan tugasnya masing-masing, yang sebagai satu kesatuan mempunyai tujuan tertentu dan mempunyai batas-batas yang jelas, sehingga bisa dipisahkan secara tegas dari lingkungannya. Menurut Sutarto (1985) bahwa organisasi adalah sistem yang saling berpengaruh antar orang dalam kelompok yang bekerjasama untuk mencapai tujuan tertentu. Menurut Herbert and Gullet bahwa yang dimaksud dengan pengorganisasian merupakan proses yang mana struktur suatu organisasi dibuat dan ditegakan. Proses ini meliputi ketentuan dari kegiatan-kegiatan yang spesifik yang perlu untuk menyelesaikan semua sasaran organisasi, pengelompokan kegiatan tersebut berkaitan dengan susunan yang logis, dan tugas dari kelompok kegiatan ini bagi suatu jabatan atau orang yang bertanggung jawab. Barnard berpendapat bahwa organisasi adalah suatu sistem aktivitas kooperatif antara dua orang atau lebih. Organisasi merupakan pengelompokan orang-orang ke dalam aktivitas kerjasama untuk mencapai tujuan yang telah ditetapkan, sedangkan pengorganisasian adalah aktivitas orangorang dalam mengelompokan, menyusun dan mengatur berbagai macam pekerjaan yang perlu diselenggarakan untuk mencapai tujuan pendidikan dalam (Henry Fayol, 1974). Organisasi merupakan penugasan orang-orang ke dalam fungsi pekerjaan yang harus dilakukan agar terjadi aktivitas kerjasama dalam mencapai tujuan. Sedangkan pengorganisasian merupakan penyusunan dan pengelompokan bermacam-macam pekerjaan berdasarkan jenis pekerjaan, urutan sifat dan fungsi pekerjaan, waktu dan kecepatan(Tim, n.d.)

\section{b. Konsep Collaborative governance}

Ansell and gash menjelaskan setrategi baru dari pemerintah disebut sebagai pemerintahan kolaboratif atau collaborative governance. Bentuk dari governace yang melibatkanberbagai stakeholders atau pemangku kepentingsn secara bersamaan di dalam sebuah forum dengan aparatur pemerintah untuk membuat keputusan Bersama. (Ansell dan Alison, 2007:543)(Governance et al., n.d.) Lebih lanjut menurut Ansel dan Gash, collaborative governance adalah suatu pengaturan pemerintahan dimana satu atau lebih lembaga pubik secara langsung melibatkan para pemangku kepentingsn non-pemerintah dalam proses pengambilan keputusan kolektif yang bersifat formal, beroriantasi pada consensus, dileberaktif yang bertujuan untuk membuat dan menerapkan kebijakan public serta mengelola progam ataupun aset public.(Governance et al., n.d.)

O’lyn dan Wanna mengartikan kolaborasi sebagai bekerja sama atau bekerja sama dengan orang lain. Hal tersebut menyiratkan bahwa seseorang aktor atau seorang individu atau kelompok atau organisasi orang melakukan kerja sama dengan yang lainya hal tersebut sangat bervariasi.(Wargadinata, n.d.) Sejalan dengan definisi yang disampaikan Dwiyanto, Sink menjelaskan kerjasama kolaboratif sebagai proses dimana organsiasi-organisasi yang memiliki suatu kepentingan terhadap suatu masalah tertentu berusaha mencari solusi yang ditentukan secara bersama dalam rangka mencapai tujuan yang mereka tidak mencapainya secara sendirisendiri.(Febrian, 2016)

Collaborative governance menurut Ratner terdapat tiga fokus fase atau tiga tahapan yang merupakan proses kolaborasi dalam tata kelola pemerintahan. (Ratner, 2012:5) dapat dilihat pada gambar berikut ini mengenai permasalahan dan stakeholders lain saling mendengarkan setiap permasalahan yang diterangkan oleh setiap stakeholders yang terlibat. Kemudian memperhitungkan mengenai peluang dalam penyelesaian setiap permasalahan yang telah diidentifikasi, seperti solusi dari permasalahan yang akan terjadi. Setiap stakeholders memiliki kewenangan yang 
sama dalam menentukan kebijakan pada setiap permasalahan yang telah diidentifikasi dan memperhitungkan peluang berupa achievment yang dapat diperoleh dari masing-masing pihak yang terlibat. Pada dasarnya, fase ini merupakan fase saling mendengarkan mengenai permasalahan dan kesempatan untuk dapat memanfaatkan dari setiap permasalahan yang diterangkan oleh masing-masing stakeholders.(Irawan, 2017)

Collaborative Governance juga diartikan sebagai sebuah pengaturan yang mengatur satu atau lebih lembaga publik secara langsung terlibat dengan pemangku kepentingan non publik dalam proses pengambilan keputusan kolektif bersifat formal, berorientasi konsensus, dan musyawarah yang bertujuan untuk membuat atau mengimplementasikan kebijakan publik atau mengelola program atau aset publik. (Ansell dan Gash. 2007.) Tulisan ini mencoba menganalisis potensi pembangunan kawasan perdesaan berbasis Collaborative Governance untuk membantu berbagai pihak yang akan mengembangkan dan mengimplementasikan pembangunan kawasan perdesaan dalam bentuk kebijakan maupun penelitian.(Febrian, 2016)

Jika dapat kita simpulkan secara lebih sederhana bahwa collaborative governance adalah konsep yang di maknai sebagai kerjasama dalam bentuk interaksi dan kompromi dari pemrintah terhadap steak holder atau masyarakat dan elemen terkait yang secara langsung merasakan akibat dan manfaat. Seperti yang terjadi di Ponorogo di Desa Bringinan pemanfaatan konsep collaborative governance sangat di perlukan guna dapat menggandeng elemen elemen masyarakat dapat lebiih aktif dalam pembangunan desa. Salah satu konsep ini di terapkan Kepala Desa Bringinan dengan memanfaatkan masyarakat yang mayoritas bekerja sebagai pekerja imigran untuk membentuk salah satu organisasi eksternal yang di damping oleh salah satu lembaga swadaya masyarakat. tujuan di bentuknya organisasi eksternal ini agar organisasi ini dapat mempengaruhi masyarakat lebih aktif dalam penyusunan RPJM Desa. dengan berkolaborasinya antara Pemerintah desa, organisasi dan NGO akan dapat lebih efektif dalam melakukan penyusunan RPJM Desa

\section{c. Formulasi Penyusunan RPJMDesa}

Undang-undang no 6 tahun 2016 tentang Desa (UU) Desa mengamanatkan penyusunan Rencana Panjang Jangka Menengah Desa (RPJM Desa). RPJMDesa (Rencana Pembangunan Jangka Menengah Desa) dibuat sebagai akibat adanya otonomi daerah. RPJM-Desa adalah dokumen pembangunan selama enam tahun yang didasarkan visi dan misi kepala desa terpilih. Pendekatan yang digunakan dalam RPJM-Desa ini adalah singkronasi pendekatan top-down dengan bottom-up, dimana rancangan program pembangunan yang sudah dibuat pemerintah desa didiskusikan kembali melalui wahana politik desa. Pembuatan RPJM-Desa perlu mendapat dorongan yang lebih besar dari berbagai elemen masyarakat guna mencapai kebijakan pembangunan yang efektif. Dalam UU Desa Pasal 3 menyebut bahwa asas pengaturan desa yaitu asas: (1) rekognisi, (2) subsidiaritas, (3) keberagaman, (4) kebersamaan, (5) kegotongroyongan, (6) kekeluargaan, (7) musyawarah, demokrasi, (9) kemandirian, partisipasi, (11) kesetaraan, pemberanan, (13) keberlanjutan, pemberdayaan, dan (13) keberlanjutan, penyusunan RPJMDesa melalui formulasi yaitu,

1. Persiapan

2. Pembentukan tim 11

3. Penyelarasan arah kebijakan pembangunan kabupaten/kota

4. Pengkajian keadaan Desa

5. Penyusunan pembangunan Desa melalui masyawarah Desa

6. Penyusunan RPJM Desa

7. Penyusunan pembangunan melalui Musrembangdes

Pembentukan Tim Penyusun RPJM

Desa Bringinan telah dilakukan secara 
partisipatif melibatkan aparatur pemerintahan desa, Badan Permusyawaratan Desa (BPD) dan unsur masyarakat dalam sebuah rapat. Dengan berpedoman pada Pemendagri 114 tahun 2014 tentang Pedoman Pembangunan Desa maka, ditetapkanlah nama-nama yang akan masuk dalam Tim Penyusun RPJMDesa Bringinan. Pembentukan tim tersebut ditandai dengan penerbitan surat Keputusan Kepala Desa. Dapat di simpulkan penyusunan RPJM Desa adalah penyusunan pembangunan desa yang, melibatkan elemen-elemen masyrakat dengan melakukan musyawarah untuk penyusunan rencana kerja kepala desa yang terpilih selama 6 tahun.

\section{d. Organisasi eksternal di Desa}

Organisasi eksternal adalah suatu wadah atau tempat berkumpulnya sekelompok orang untuk bekerja sama secara rasional, sistematis, terkendali, dan terpimpin untuk mencapai suatu tujuan tertentu dengan memanfaatkan sumber daya yang ada. Dalam dunia pemerintahan dan sosial ada banyak organisasi internal maupun eksternal yang sekarang berkembang di desa contoh organisasi internal dalam pemerintahan desa yaitu birokrasi pemerintahan yang menjalankan pemerintahan desa lingkup RT maupun RW. Organisasi Eksternal dalam dunia sosial maupun politik sangat banyak contoh organisasi tersebut adalah LSM, PARPOL, karang taruna, gapoktan dan banyak lainnya ..(Pendidikan \& Fis, 2013)

Contoh organisasi eksternal yang ada di Desa Bringinan yaitu; pertama karang taruna adalah salah satu organisasi non pemerintah yang berada di desa yang masih aktif. Karang taruna adalah salah satu organisasi kemasyarakatan sebagai wadah dan sarana pengembangan setiap anggota masyarakat yang tumbuh dan berkembang atas kesadaran dan tanggung jawab sosial dari, oleh dan untuk masyarakat terutama generasi muda di wilayah desa. (Taqwarahmah \& Setiyawati, 2017). Berdasarkan pengertian tersebut bahwa karang taruna adalah suatu organisasi kemasyarakatan yang berada di desa sebagi wadah generasi muda yang bergerak di bidang kesejahteraan sosial.

Kedua gapoktan adalah salah satu organisasi di desa untuk memperkuat kelambagaan petani yang telah ada sehingga pembinaan pemerintah kepada petani terfokkus dan memiliki tujuan yang jelas (Wahyuni \& Pasaribu, 2013). Gapoktan merupakan organisasi non formal dari sekelompok petani yang bergabung memiliki tujuan guna meningkatkan skala ekonomi dan efisiensi usaha

Ketiga, KOPI juga adalah salah satu organisasi non pemerintah yang ada di desa bringinan KOPI adalah KOMUNITAS PERKERJA IMIGRAN, kopi ini di buat guna dapat menampung permaslahan pekerja imirgan, kopi tidak hanya betrjalan sendiri tetapi KOPI ini di bimbing oleh infest dari jogja. Kopi ini di bentuk di desa bringinan di karenakan pekerja imigran di desa bringinan sudah mencapai 300 orang dalam satu desa. Dengan berjalanya waktu kopi bersinergi dengan pemerintahan desa, kopi mulai ikut serta dalam pembangunan desa. Dapat di simpulkan dengan adanya organisasi eksternal (KOPI) yang meskipun beranggotakan hanya pekerja imigran tetapi organisasi eksternal yang ada didesa ini dapat mempengaruhi terhadap masyarakat desa agar lebih aktif ikut serta dalam pembangunan desa. Hal ini menjadi ciri khas sekaligus pembeda dengan desa lainnya. KOPI merupakan organisasi eksternal desa yang hanya di miliki di 3 desa se-Kabupaten Ponorogo.

\section{e. Keterlibatan KOPI dalam Penyusunan RPJMDesa}

RPJMDesa merupakan suatu dokumen perencanaan untuk jangka menengah yang memuaat visi, misi, kebijakan, serta rencana kegiatan desa untuk mencapai tujuan yang telah dicitacitakan. Penyusunan RPJMDesa dengan menerapkaan prinsip partisipatif, yakni melibatkan masyarakat dalam proses penyusunannya sehingga tercipta program kerja yang sesuai dengan kebutuhan masyarakat. Di Desa Bringinan 
Kecamatan jambon Kabupaten Ponorogo penyusunan RPJM Desa melibatkan kepala desa, BPD, tokoh masyarakat, serta salah satu organisasi eksternal desa yakni KOPI.

Berdasarkan hasil wawancara tentang keterlibatan KOPI dalam penyusunan RPJMDesa, awal mula masuknya KOPI di Desa Bringinan yaitu KOPI dengan bantuan infest dari Yogyakarta menentukan desa yang dipilih dengan melihat beberapa aspek seperti halnya dari potensi pekerja imigran di Ponorogo dan juga melihat tingkat keaktifan kepala desa dalam melakukan inovasi-inovasi pembangunan desa. Sehingga kepala desa dapat mempengaruhi masyarakat agar menjadi lebih aktif dalam pembangunan desa. Dan desa bringinan terpilih karena termasuk dalam kriteria aspek penentuan tersebut.

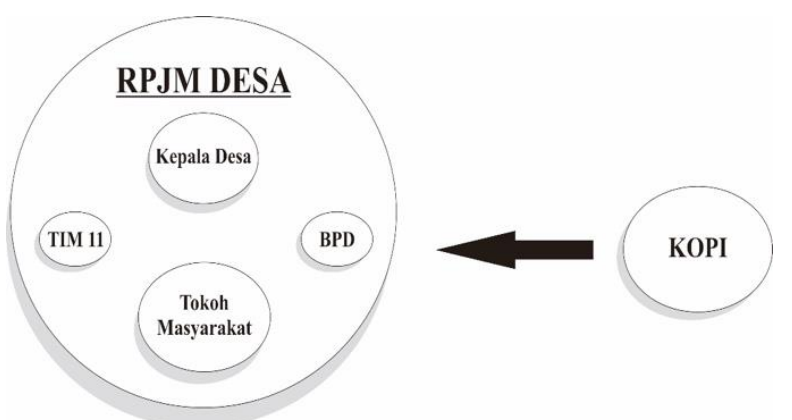

Gambar 1. Posisi KOPI dalam Penyusunan RPJMDesa

Gambar di atas dapat dijelaskan, KOPI sebagai organisasi non pemerintah yang ikut serta dalam penyusunan RPJMDesa yaitu sebagai wadah aspirasi masyarakat. KOPI sebagai salah satu organisasi eksternal yang berada di Desa Bringinan setara dengan karang taruna, gapoktan, bumdes, dan organisasi ekternal lainnya. Pembedanya adalah pada tugas pokok dan fungsi. KOPI bertugas membantu pemerintah desa dalam melakukan pembentukan karakter, peningkatan sumber daya manusia dan keterampilan masyarakat Desa Bringinan. Sedangkan karang taruna dan organisasi lainnya hanya berfokus pada kegiatan sosial kemasyarakatan saja. Kopi ini memiliki kegiatan unggulan dalam keterlibatan penyusunan RPJM Desa, PAD adalah progam unggulan yang di yakini dapat membantu pemerintah desa bringinan guna dapat membantu manggandeng elemen elemen masyarakat sehingga kopi mudah dalam penggalian data, Perencanaan apresiatif desa merupakan perencanaan pembangunan yang berdasarkan pada potensi dan data yang ada di desa tersebut. Oleh karena itu, penggalian data di desa menjadi hal yang sangat penting sebagai dasar dalam perencanaan pembangunan di desa. Berdasarkan hal tersebut, Infest bermaksud mengadakan pelatihan perencanaan apresiatif desa di tiga desa dampingan di wilayah Kabupaten Ponorogo, tujuan adanya PAD adalah dipahaminya aspek-aspek dalam perencanaan apresiatif desa oleh peserta, disepakatinya indikator-indikator pada setiap aspek perencanaan desa yang mencakup kewenangan desa, aset desa, indikator kesejahteraan desa, usulan kelompok marjinal untuk pembangunan desa, dan perbaikan pelayanan publik desa, dipetakannya setiap aktor yang dapat terlibat secara partisipatif dalam penggalian data perencanaan desa dan dirumuskannya kerangka kerja, rencana waktu dan prioritas kegiatan dalam penggalian potensi desa. Adapun keluaran yang ingin dicapai dari kegiatan ini adalah, adanya tim pembaharu desa di desa dampingan yang mengurusi setiap aspek perencanaan desa yang mencakup kewenangan desa, aset desa, indikator kesejahteraan desa, usulan kelompok marjinal untuk pembangunan desa, dan perbaikan pelayanan publik desa, Rencana kerja pemetaan apresiatif desa, Adanya indikator-indikator pada setiap aspek perencanaan apresiatif yang disusun oleh masing- masing kelompok yang bertanggung jawab untuk setiap isu, Adanya rencana kerja tindak lanjut yang disepakati oleh tim pembaharu desa. KOPI memiliki 5 tim pembaharu desa yang dapat menaggali data sebagai acuan pemerintah guna dalam penyusunan RPJM Desa 5 tim tersebut yaitu; 


\section{1) Tim kewenangan desa}

Tim kewenangan desa adalah tim yang menggali kewenangan yang dimiliki desa meliputi kewenangan pada bidang penyelenggaraan pemerintah Desa, Pembinaan kemasyarakatan Desa, dan pemberdayaan Masyarakat Desa berdasarkan prakarsa Masyarakat, hak asal usul dan adat istiadat Desa, dengan adanya KOPI ini desa lebih mengetahui kewenangan Desa dan apa saja kewenangan yang dapat dibangun dari segi infrastruktur, maupun lingkup kesejahteraan masyarakat Desa Bringinan KOPI juga membuatkan raperdes Desa Bringinan supaya mengetahui kewenangan hak asal usul dan kewenangan lokal berskala Desa.(RAPERDES KEWENANGAN DESA BRINGINAN, n.d.)

2) Tim penggalian usulan kelompok marginal

Kelompok marginal ini adalah kelompok orang-orang atau masyarakat Desa Bringinan yang terpinggirkan, dengan adanya organisasi eksternal ini dalam keterlibatan penyusunan RPJMDesa, organisasi ini melakukan pendekatan dengan masyarakat marginal dengan menyaring usulan-usulan yang mungkin dapat dimasukkan ke dalam RPJMDesa. Kelompok Marginal ini dibimbing KOPI dengan mengadakan pelatihan atau seminar tentang pembangunan desa dan dapat mengerti betapa pentingnya masyarakat dalam pembangunan desa, dengan adanya pelatihan tersebut masyarakat atau kelompok marginal mulai mengusulkan usulan-usulan yang dapat di jadikan acuan dalam penyususnan RPJM Desa

3) Tim kesejahteraan lokal desa

Pengertian Kesejahteraan ada beberapa tentang pengertian kesejahteraan antara lain menurut Depdiknas (2001:1011) kesejahteraan adalah hal atau keadaan sejahtera, aman selamat, dan tentram. Sedangkan menurut BKKBN (1994:5) keluarga sejahtera adalah keluarga yang dibentuk berdasarkan perkawinan yang sah, mampu memenuhi kebutuhan hidup spritual dan materi yang layak, bertaqwa kepada Tuhan Yang Maha Esa, memiliki hubungan yang selaras, serasi, dan seimbang antar anggota dan antar keluarga dengan masyarakat dan lingkungan.

Dengan kedua pengertian di atas dapat disimpulkan bahwa kesejahteraan keluarga tidak hanya menyangkut kemakmuran saja, melainkan juga harus secara keseluruhan sesuai dengan ketentraman yang berarti dengan kemampuan itulah dapat menuju keselamatan dan ketentraman hidup. Ada 3 (tiga) model pengukuran kesejahteraan dan kemiskinan yang lazim dipakai oleh pemerintah Indonesia. Ketiga model tersebut adalah Badan Kependudukan dan Keluarga Berencana Nasional (BKKBN), Badan Pusat Statistik (BPS) dan Human Development Index (HDI) UNDP. Masing-masing memiliki cara pandang dan lingkup pengertian yang berbeda. Dari ketiga model tersebut kesejahteraan keluarga dari BKKBN adalah satusatunya yang dilakukan secara rutin setiap tahun dan memiliki tingkat detail sampai pada tingkat desa bahkan sampai pada tingkat Rukun Tetangga. Itu alasan kenapa data ini selalu digunakan untuk program-program pemberian bantuan bagi keluarga dan penduduk miskin. Dari sisi akurasi, survei BPS memiliki kaidahkaidah statistik yang harus dijalankan dalam survei dan pengolahan data dibandingkan dengan pendataan BKKBN yang dilakukan dengan cara sederhana. Sehingga secara metodologi statistik, model tingkat konsumsi BPS pasti lebih dapat dipertanggungjawabkan. Namun metodologi bukan satu-satunya faktor yang menjamin akurasi, karena masih banyak faktor lain seperti tingkat disiplin, komitmen serta kejujuran dari orangorang yang terlibat di dalam survei. Dari sisi fleksibilitas standar, model BPS lebih fleksibel dalam penilaian.

BKKBN mengharuskan orang untuk makan telur atau daging atau ikan paling kurang sekali dalam seminggu, padahal mungkin ada orang yang sangat mampu 
untuk membeli komoditas makanan tersebut, tapi karena alasan kepercayaan atau kesehatan mereka tidak mau makan. Dalam model BPS hal tersebut tidak dipedulikan, asalkan tingkat konsumsinya lebih besar dari garis kemiskinan. Pada dasarnya orang tersebut mampu untuk mendapatkannya, kemudian pada kenyataannya ternyata orang tersebut menghabiskan lebih dari setengah konsumsi makanannya untuk rokok, maka dari itu bukan persoalan kemampuan melainkan persoalan pola konsumsi. Dari sisi definisi dan indikator, jelas terlihat bahwa Model Pembangunan Manusia dari UNDP melihat kemiskinan atau kesejahteraan atau kualitas hidup secara lebih luas dibandingkan model kesejahteraan keluarga dari BKKBN, apalagi jika dibandingkan dengan model tingkat konsumsi dari BPS. Namun demikian, laporan Pembangunan Manusia sangat terbatas hanya tiga tahun sekali dan umumnya hanya sampai tingkat provinsi, baru pada laporan tahun 2001 untuk keadaan tahun 1999 yang juga melaporkan tingkat kabupaten. Karena masing-masing model memiliki kelebihan dan kekurangan bahkan memiliki tujuan serta definisi yang berbeda, maka Pemerintah Desa Bringinan harus memilih secar hati-hati sesuai dengan tujuan, kebutuhan dan kondisi Desa Bringinan.

Dari paparan di atas, pemerintah desa menyadari perlunya menciptakan pengukuran kesejahteraan masyarakat yang terintegrasi dengan perencanaan pembangunan desa, pengelolaan keuangan desa dan formulasi kebijakan desa. Sensus kesejahteraan ini harus memungkinkan pemerintah desa sebagai pengambil kebijakan untuk dapat mendukung rumah tangga miskin agar memiliki peluang untuk secara terus menerus memperbaiki kehidupannya sehingga dapat terbebas dari situasi yang rentan. Dalam jangka pendek, sensus harus dapat memberikan data dan informasi yang tepat tentang rumah tangga sejahtera dan miskin, sehingga program-program bantuan dan program pembangunan dapat didistribusikan secara tepat sasaran. Sensus harus dilaksanakan berdasarkan indikator-indikator yang mencakup persepsi kesejahteraan menurut masyarakat di Desa Bringinan ditambah dengan prinsip-prinsip umum pembangunan berkelanjutan. Walaupun demikian, indikator harus tetap sederhana, mudah dipahami dengan jumlah yang tidak terlalu banyak sehingga dapat diterapkan dengan biaya yang tidak mahal.

\section{4) Tim penggaliann asset dan potensi desa}

Berdasarkan Undang-undang No. 6 Tahun 2014, desa memiliki kewenangan untuk mengelola dan memanfaatkan aset yang dimiliki dalam rangka melaksanakan pembangunan dengan tujuan untuk meningkatkan kesejahteraan masyarakat desa. Kewenangan mengelola aset desa dipertegas melalui Peraturan Menteri dalam Negri (Permendagri) No. 1 Tahun 2016 tentang pengelolaan aset desa. Berdasarkan aturan tersebut, jenis aset desa yang dimaksud adalah kekayaan asli desa, serta kekayaan yang diperoleh dari hibah, sumbangan, hasil kerja sama desa (pasal 2). Yang dimaksud dengan kekayaan desa Permendagri tersebut terdapat paling tidak 11 jenis kekayaan asli desa, diantaranya: tanah, kas desa, pasar desa, pasar hewan, tembatan perahu, bangunan desa, pelelangan ikan, pelelangan hasil pertanian, hutan milik desa, mata air, pemandian umum dan lainlain kekayaan asli desa. Dengan adanya KOPI pemerintah dapat mengetahui aset dan potensi desa yang dapat dikembangkan di Desa Bringinan, contoh pembangunan makam tua sebagai makam religius.

\section{5) Tim survei layanan publik}

Penyelenggaraan pelayanan publik merupakan salah satu fungsi penting pemerintahan yang merupakan kegiatan riil yang diberikan masyarakat kepada pemerintah. Salah satu tujuan hadirnya UU No. 6 Tahun 2014 tentang desa adalah perwujudan kesejahteraan umum tujuan ini diharuskan aparatur pemerintah dituntut untuk bisa memberikan pelayanan 
semaksimal mungkin kepada masyarakat. Tim survei perbaikan pelayanan publik Desa Bringinan berdasarkan kesepakatan, musyawarah Desa Bringinan untuk menyepakati prioritas perbaikan layanan publik, ada 14 jenis perbaikan prioritas pelayanan publik di Desa Bringinan. Perbaikan layanan tersebut terdiri dari pelayanan administrasi, pelayanan barang publik, dan layanan jasa publik. Berdasarkan 14 jenis prioritas perbaikan layanan tersebut, terdapat 22 pertanyaan dan ditanyakan kepada 303 responden di Desa Bringinan.(Laporan Data Tim Survei Layanan Publik, n.d.)

Masing masing tim ini akan menghasilkan data akurat yang ada di Desa Bringinan dan kemudian akan dipakai dalam acuan pemerintah Desa Bringinan dalam penyusunan RPJMDesa, RKPDesa, dan APBDesa

\section{KESIMPULAN}

Berdasarkan hasil temuan data lapangan yang telah disajikan dan di analisis sebelumnya, dapat di simpulkan dalam formulasi penyusunan RPJM Desa menurut UU penyusuanan RPJM Desa di bentuk oleh Kepala Desa, BPD, tokoh masyarakat, dan tim 11. Di Ponorogo tepatnya di Desa Bringinan adanya kolaborasi antara pemerintah desa dan organisasi eksternal dalam melakukan penyusunan RPJM Desa yang seharusnya tidak di tuangkan dalam undang- undang penyusunan RPJM Desa. Kolaborasi ini adalah salah satu satu konsep untuk memecahkan masalah masyarakat di mana adanya kolaborasi dari pemerintah, swasta dan masyarakat sehingga permasalhaan akan bisa diatasi. Meskipun dalam peraturan perundang-undangan telah disusun batasan keterlibatan masyarakat dalam penyusunan RPJMDesa tetapi melihat fenomena di Desa Bringinan maka perlu adanya organisasi eksternal Desa untuk ikut serta dalam merencanakan pembangunan Desa. Fenomena ikut sertanya KOPI dalam penyusunan RPJMDesa bukan tanpa alasan, hal ini terjadi karena di Desa Bringinan banyak masyraakatnya bekerja sebagai Buruh Migran dan KOPI adalah organisasi yang bergerak dalam bidang pemberdayaan serta perlingan buruh migran dari Desa Bringinan. Selain itu, kolaborasi antara KOPI dan pemerintah Desa ini muncul karena kurangnya keterlibatan masyarakat dalam penyusunan RPJM Desa untuk megatasi segala permasalahan buruh migran asal Desa Bringinan. Organisasi KOPI ini terbukti telah bisa memberikan masukan-masukan penting dalam penyusunan rencana pembangunan Desa yang dituangkan dalam RPJMDesa melalui data-data yang sudah dikumpulkan KOPI dari lapangan.

Organisasi KOPI ini memiliki bertugas dalam penggalian data tentang masyarakat Desa Bringinan yang meliputi sensus kesejahteraan, survei layanan publik, aset dan potensi desa, kewenangan lokal desa, dan menggali gagasan kelompok marjinal yang selanjutnya dijadikan acuan untuk menyusun RPJMDesa. Selain itu juga, KOPI juga sebagai wadah aspirasi masyarakat, menyerap semua usulan-usulan dari masyarakat desa bringinan meskipun dari kelompok marginal, KOPI menggali data apa saja yang ada di Desa Bringinan sehingga pemerintah desa lebih mudah dalam melakukan penyusunan RPJMDesa. Pemerintah Desa Bringinan dengan melibatkan organisasi eksternal KOPI dalam penyusunan RPJMDesa merupakan kolaborasi yang sangat bagus karena tentu KOPI yang lebih dekat dengan masyarakat atau buruh migran akan memiliki data yang banyak serta terperinci terkait dengan kebutuhan masyarakat untuk bisa dijadikan acuan dalam penyusunan RPJMDesa.

Cara menggali data, KOPI mempunyai 5 tim pembaharu yaitu tim kewenangan desa, tim penggalian usulan kelompok marginal, tim kesejahteraan lokal desa, tim penggalian aset dan potensi desa, dan tim layanan publik. Data yang diperoleh dari KOPI ini akan dijadikan landasan oleh pemerintah desa sebagai program kerja kedepan pemerintah Desa Bringinan. Karena lembaga ini adalah lembaga swadaya masyarakat maka dana dalam penggalian data tidak ikut dalam anggaran pemerintah Desa, sehingga Desa juga tidak akan terbebani dengan keberadaan KOPI ini.

Tetapi sekali lagi, keterlibatan organisasi eksternal KOPI dalam penyusunan 
RPJMDesa ini secara tidak langsung memberikan kritik terhadap peraturan perundang-undangan yang ada terkait dengan penyusunan RPJMDesa. Munculnya konsep kolaboratif ini tentu akan menguntungkan kedua belah pihak dimana Desa akan mendapatkan masukkan yang baik berdasarkan kebutuhan riil masyrakaatnya, sedangkan Organisasi KOPI akan mendapatkan keuntungan masukan yang dititipkan masyarakat kepada KOPI bisa diterima bahkan diimplementasikan melalui rencana pembangunan Desa. Dengan adanya riset ini maka kosep-konsep kolaborasi antara pemerintah dan pihak eksternal dalam penyusunan rancanagan penbanguan harus ditinjau ulang dimana "masyarakat" dalam hal ini yang perlu dilibatkan adalah masyarakat yang tahu benar atau paham benar dengan kebutuhan masyarajat secara luas dan bukan hanya masyarakat dalam kalangan tertentu. "Masyarakat" dalam penyusunan perencanaan pembangunan melalui penelitian ini juga tidak harus peronal tetapi juga bisa dalam bentuk organisasi eksternal dikarenakan organisasi eksternal tentu memiliki masukan yang memiliki dasar serta lebih terstruktur dengan baik.

\section{DAFTAR PUSTAKA}

Febrian, R. A. (2016). COLLABORATIVE GOVERNANCE DALAM PEMBANGUNAN KAWASAN PERDESAAN ( Tinjauan Konsep dan Regulasi ). II, 200-208.

Governance, C., Pemerintahan, D., Governance, C., \& In, S. (n.d.). Collaborative governance dalam pemerintahan 1 collaborative governance strategy in government sector. 196-210.

Irawan, D. (2017). ( Studi Deskriptif Proses Pemerintahan Kolaboratif Dalam Pengendalian Pencemaran Udara di Kota Surabaya ). 5, 1-12.

Laporan data tim survei layanan publik. (n.d.).

Pendidikan, J., \& Fis, S. (2013). Integrasi Organisasi Masyarakat Sipil ( Civil Social Organization ) di Lingkungan Sekolah. 10(1).

Raco, R. (n.d.). METODE PENELITIAN
KUALITATIF

RAHMA FITRIAYU SARI, A. F. (2019).

KAJIAN

MASYARAKAT

PARTISIPASI

PENYUSUNAN

PEMBANGUNAN

DALAM

RENCANA

JANGKA

MENENGAH DESA DI DESA

PANDOWOHARJO, KECAMATAN

SLEMAN. Journal of Chemical Information and Modeling, 53(9), 16891699.

https://doi.org/10.1017/CBO9781107415 324.004

Rahman, A., Desa, P., Kebijakan, F., Perencanaan, P., \& Jangka, P. (2014). FORMULASI

KEBIJAKAN

PENYUSUNAN RENCANA

PEMBANGUNAN JANGKA

MENENGAH ( RPJM ) DESA SUNGAI AMBAWANG KUALA KECAMATAN SUNGAI AMBAWANG KABUPATEN KUBU RAYA.

RAPERDES KEWENANGAN DESA BRINGINAN. (n.d.).

Taqwarahmah, C. G., \& Setiyawati, D. (2017). Peran Karang Taruna Dalam Pemberdayaan Penyandang Disabilitas Di Desa Karangpatihan , Kabupaten Ponorogo Dan Implikasinya Terhadap Ketahanan Ekonomi Keluarga. 9340(2), 37-48.

Tim, A. (n.d.). Hand out Teori Organisasi. Wahyuni, S., \& Pasaribu, S. M. (2013). Strategi Percepatan Transformasi Kelembagaan Gapoktan dan Lembaga Keuangan Mikro Agribisnis Dalam Memperkuat Ekonomi di Perdesaan. 10(1), 60-70.

Wargadinata, E. (n.d.). KEPEMIMPINAN KOLABORATIF Ella Wargadinata 1. VIII, 1-14. 